\title{
Comparative studies of essential oils of Clausena anisata (Hook) using solvent-free microwave extraction and hydrodistillation methods
}

\begin{tabular}{|c|c|}
\hline \multicolumn{2}{|c|}{$\begin{array}{l}\text { Authors: } \\
\text { lbraheem O. Lawal }^{1} \text { (1) } \\
\text { Hilda Ajay } \\
\text { Paul Dairo } \\
\text { Paul O. Ogunbamowo }\end{array}$} \\
\hline \multicolumn{2}{|c|}{$\begin{array}{l}\text { Affiliations: } \\
{ }^{1} \text { Biomedicinal Research } \\
\text { Centre, Forestry Research } \\
\text { Institute of Nigeria, Ibadan, } \\
\text { Nigeria }\end{array}$} \\
\hline \multicolumn{2}{|c|}{$\begin{array}{l}{ }^{2} \text { Department of Plant and } \\
\text { Environmental Biology, } \\
\text { Kwara State University, } \\
\text { Malete, Nigeria }\end{array}$} \\
\hline \multicolumn{2}{|c|}{$\begin{array}{l}\text { Corresponding author: } \\
\text { Ibraheem Lawal, } \\
\text { ibroodula@yahoo.com }\end{array}$} \\
\hline \multicolumn{2}{|c|}{$\begin{array}{l}\text { Dates: } \\
\text { Received: } 24 \text { Mar. } 2018 \\
\text { Accepted: } 17 \text { Nov. } 2018 \\
\text { Published: } 15 \text { Apr. } 2019\end{array}$} \\
\hline \multicolumn{2}{|c|}{$\begin{array}{l}\text { How to cite this article: } \\
\text { Lawal, I.O., Ajay, H., Dairo, P. } \\
\text { \& Ogunbamowo, P.O., 2019, } \\
\text { 'Comparative studies of } \\
\text { essential oils of Clausena } \\
\text { anisata (Hook) using } \\
\text { solvent-free microwave } \\
\text { extraction and } \\
\text { hydrodistillation methods', } \\
\text { Journal of Medicinal Plants } \\
\text { for Economic Development } \\
\text { 3(1), a59. https://doi. } \\
\text { org/10.4102/jomped.v3i1.59 }\end{array}$} \\
\hline \multicolumn{2}{|c|}{$\begin{array}{l}\text { Copyright: } \\
\text { (c) 2019. The Authors. } \\
\text { Licensee: AOSIS. This work } \\
\text { is licensed under the } \\
\text { Creative Commons } \\
\text { Attribution License. }\end{array}$} \\
\hline \multicolumn{2}{|l|}{ Read online: } \\
\hline 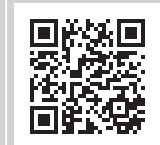 & $\begin{array}{l}\text { Scan this QR } \\
\text { code with your } \\
\text { smart phone or } \\
\text { mobile device } \\
\text { to read online. }\end{array}$ \\
\hline
\end{tabular}

Background: Essential oils have been used for medical purposes because of their medicinal properties and are sourced from natural products.

Aim: The comparative study of essential oils from Clausena anisata leaves obtained through two methods of extraction was undertaken.

Setting: C. anisata leaves were collected from Akinsola village in Ido Local Government Area of Oyo State, Nigeria.

Methods: Essential oil was extracted using the methods of solvent-free microwave extraction (SFME) and hydrodistillation (HD) and then analysed using gas chromatography coupled with mass spectrometer (GC-MS).

Results: The result shows that the essential oils obtained from the leaves of C. anisata through SFME and HD are pale yellow and colourless, respectively. A higher oil yield of $5.2 \mathrm{~mL} / 100 \mathrm{~g}$ was obtained through SFME compared to $3.7 \mathrm{~mL} / 100 \mathrm{~g}$ obtained through HD. There was an abundance of monoterpenes in the oil obtained using HD, while sesquiterpenes were the dominant compounds in the oil extracted using SFME. Other compounds present were $\alpha$-cubebene, $\alpha$-copaene and $\alpha$-pinene with 1091.63, 1091.64 and 979.35, respectively.

Conclusion: The compounds obtained which are very important in the cosmeceutical and pharmaceutical industries, is dependent on the method of essential oil extraction.

Keywords: Clausena anisata; Essential Oil; Hydrodistillation; Solvent-Free Extraction; Gas Chromatography-Mass Spectrometer.

\section{Introduction}

The use of plants for medicinal purposes dates back to early man. Medicinal plants have played a pivotal role in both ancient and modern cultures, with a large human population in developing countries greatly depending on plant resources for health care because they are cheaper and safer and have little or no side effects when compared to modern synthetic drugs (Agbor \& Ngogang 2005). It is believed that plants not only possess nutritional properties but also medicinal values (Kala 2005). Pharmaceutical, food and cosmetic industries extensively use plant extracts. Also, it is important to study medicinal plants in order to document their active chemical compounds and various functions in curing different kinds of ailments (Nostro et al. 2000).

Herbs play a vital role in maintaining human health. Volatile oils or essential oils have been used for medical purposes because of their medicinal properties and are sourced from natural products. They assume great importance because of their antioxidant capacities (Rohloff 2003). Essential oils are secondary plant metabolites known for their fragrance and food flavour properties. They consist of complex chemical compounds such as monoterpenes and sesquiterpenes, phenyl propanoids and oxygenated compounds (Nostro et al. 2000). Essential oils offer promising potential for future applications in the fields of agriculture, medicine, pharmaceuticals and biotechnology. This may be as a result of their function as signalling compounds produced between different types of organisms and diverse biological systems coupled with their general antimicrobial effects, antioxidative effects and medicinal properties.

Essential oils can be extracted from various plant parts through different methods, of which hydrodistillation (HD), steam distillation and steam or water distillation are the most common (Bowles 2003; Surburg \& Panten 2006). Other methods include solvent extraction, aqueous infusion, cold or hot pressing, effleurage, supercritical fluid extraction and phytonic process 
(Da Porto, Decorti \& Kikic 2009; Hunter 2009; Martínez 2008; Pourmortazavi \& Hajimirsadeghi 2007; Surburg \& Panten 2006). The discovery and identification of biologically active secondary metabolites such as essential oils from new, promising drug species is testimony to the fact that the study of medicinal plants has clearly evolved.

Clausena, owing to its medical properties, has provided numerous natural products of interest to researchers in the field of pharmacology. Clausena is a genus of about 23 species of evergreen shrubs, occurring mostly in Asia (Burkill 1997). Its widespread availability in different parts of the world, including India, Tropical Asia and South Africa, is a great advantage. They are very easy to grow, are immune to pests and diseases and can withstand heavy pruning (Swarbrick 1997). It is therefore essential to compare the chemical components of essential oils extracted from C. anisata using solvent-free microwave extraction (SFME) and HD methods.

\section{Materials and methods}

\section{Plant collection and extraction}

Clausena anisata leaves (FHI 110245) were collected from Akinsola village, Ido Local Government Area of Oyo State. The collected plant specimens were identified at Forestry Research Institute of Nigeria (FRIN), Ibadan. Voucher specimen with voucher no. FHI 110245 was deposited in the Forestry Herbarium Ibadan (FHI) of FRIN.

The leaves were washed and air-dried; the dried samples were ground and later used for essential oil extraction using the two methods of extraction.

\section{Extraction of essential oil using solvent-free microwave extraction}

SFME was performed using the Milestone Dry DIST (2004) apparatus in accordance with the operational parameters, as described by Okoh, Sadimenko and Afolayan (2011). The multimode reactor comes with a twin magnetron $(2800 \mathrm{~W}$, $2450 \mathrm{MHz}$ each) which delivers a maximum power of $500 \mathrm{~W}$ in $5 \mathrm{~W}$ increments. The rotating microwave diffusers in the unit ensure homogeneous microwave distribution throughout the plasma-coated polytetrafluoroethylene (PTFE) cavity. The attached infra-red sensor was used to regulate the temperature. The reflux of condensed water by a circulating cooling system at $5{ }^{\circ} \mathrm{C}$ was used to keep the conditions of the temperature and water constant. Clausena anisata leaves $(250 \mathrm{~g})$ were placed into the reactor without the addition of water or any solvent, with exhaustive extraction of the essential oil accomplished in $30 \mathrm{~min}$

\section{Extraction of essential oil using hydrodistillation}

Clausena anisata leaves ( $250 \mathrm{~g}$ ) were hydrodistilled for $3 \mathrm{~h}$ in an all-glass Clevenger apparatus in accordance with the description of the British Pharmacopoeia (1980), as similarly used by Okoh et al. (2011) with slight modifications, where the heat was supplied to the heating mantle $\left(100^{\circ} \mathrm{C}\right)$ and the essential oil was extracted with $51 \mathrm{~mL}$ of distilled water for $3 \mathrm{~h}$. The essential oil was collected and analysed without delay.

\section{Gas chromatography-mass spectroscopy analysis}

The chemical profiling of essential oil extracted through HD and SFME was performed using gas chromatography-mass spectroscopy (GC-MS). This was carried out using an Agilent (6890N) GC with CTC Combi Pal Autosampler and Agilent (5975B) MS. Identification of the chemical components of the essential oils was accomplished by correlating their mass spectra and retention indices with those of the Wiley 275 library (Okoh et al. 2011; Omoruyi, Afolayan \& Bradley 2014). The column type was ZB 274305, semivolatiles $(30 \mathrm{~m}$, $0.25 \mathrm{~mm}$ ID, $0.25 \mu \mathrm{m}$ film thickness). The spectrogram of each identified compound was determined by the integration of the peak areas.

\section{Results}

The essential oils obtained from the leaves of $C$. anisata through SFME and HD are pale yellow and colourless, respectively. Higher oil yield of $5.2 \mathrm{~mL} / 100 \mathrm{~g}$ was obtained through SFME compared to $3.7 \mathrm{~mL} / 100 \mathrm{~g}$ obtained through HD. The GC-MS spectral data for the essential oil obtained by HD and SFME are shown in Figures 1 and 2, respectively.

Tables 1 and 2 depict the chemical compounds present, their structures and the Kovat's index of the essential oils obtained through HD and SFME methods, respectively. Thirty-two chemical compounds were identified in the essential oil produced by HD. Some of the compounds present include $\alpha$-pinene (979.35); $\beta$-ocimene (984.08); $\alpha$-cubebene (1091.64); $\alpha$-copaene (1091.64); 3R-trans-1,3-cyclohexadiene, 1-methyl4-(1-methylethyl) - (+)-4-carene (1098.21); caryophyllene, bicyclo [7.2.0] undec-4-ene 4,11,11-trimethyl-8-methylene (1079.57); and $\beta$-panasinsene, $1 \mathrm{H}$-cyclopropa [a] naphthalene (1126.81). Other identified constituents are decahydro-1, 1,3a-trimethyl-7-methylene (1126.81); isoaromadendrene epoxide cycloheptane (1141.12); and alloaromadendrene oxide-(1) alloaromadendrene naphthalene (1164.66). Alloaromadendrene oxide-(1) alloaromadendrene naphthalene with a Kovat's index of 1164.46 has the highest concentration of sesquiterpenes.

The oil obtained from SFME showed the presence of major compounds like $\alpha$-copaene (1091.63); $\alpha$-cubebene (1091.63); 2-methylene-4,8,8-trimethyl-4-vinyl- (1105.99); and cyclohexene, 4-ethenyl-4-methyl-3-(1-methylethenyl)1-(1-methylethyl), (3R-trans)- (1095.04). Other constituents identified include naphthalene 1,2,3,5,6,8a-hexahydro-4,7dimethyl-1-(1-methylethyl)- (1131.47); caryophyllene, bicyclo [7.2.0] undec-4-ene, 4,11,11-trimethyl-8-methylene-bicyclo [5.2.0] nonane (1105.99); and cyclohexane, 1-ethenyl-1methyl-2,4-bis(1-methylethenyl)-, (1- $\alpha, 2-\beta, 4-\beta)$ (1131.47). Cyclohexane, 1-ethenyl-1-methyl-2, 4-bis (1-methylethenyl), with a Kovat's index of 1131.47 has the highest concentration 


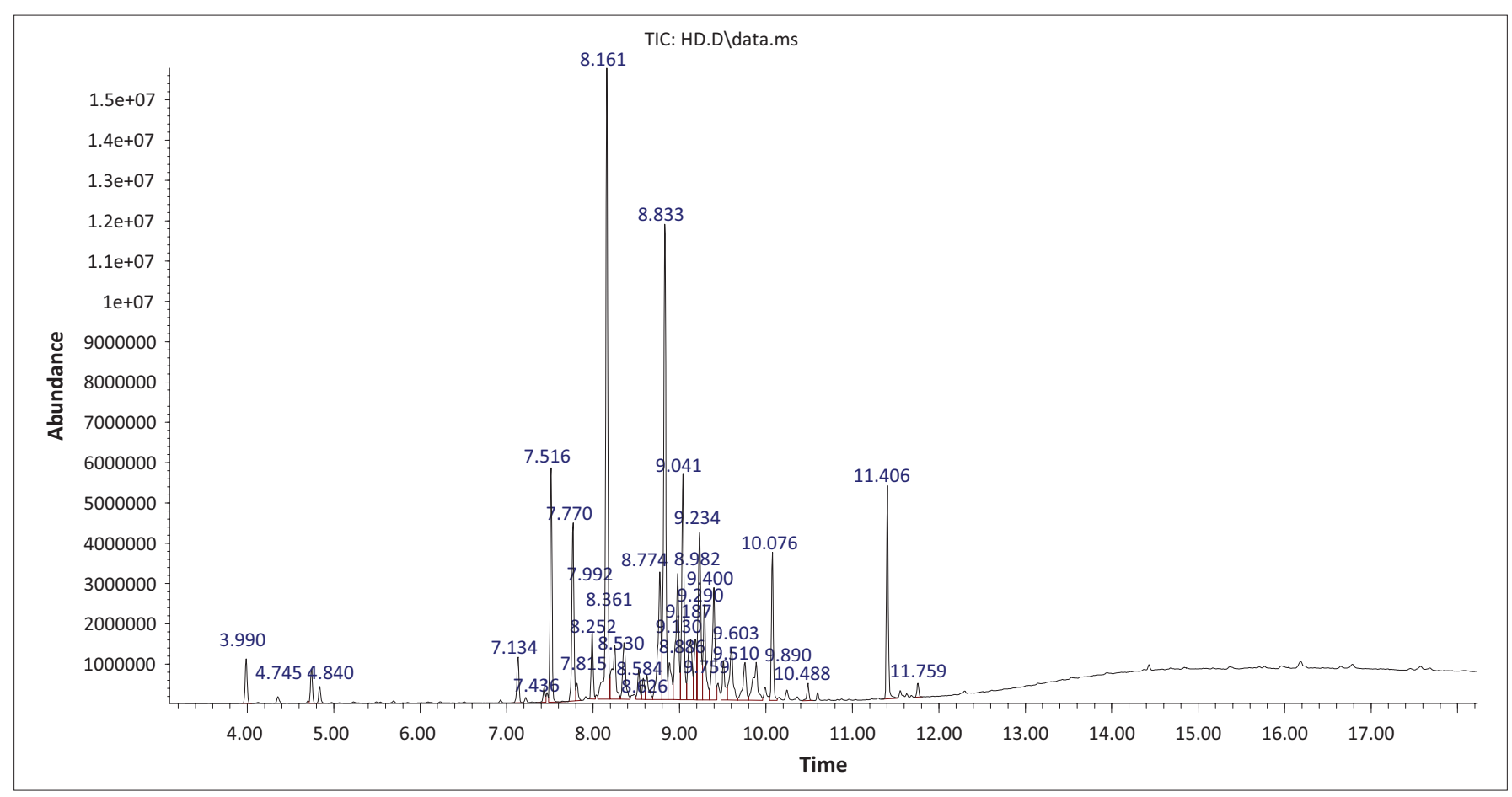

FIGURE 1: Gas chromatography-mass spectroscopy spectral data of Clausena anisata essential oil using hydrodistillation method.

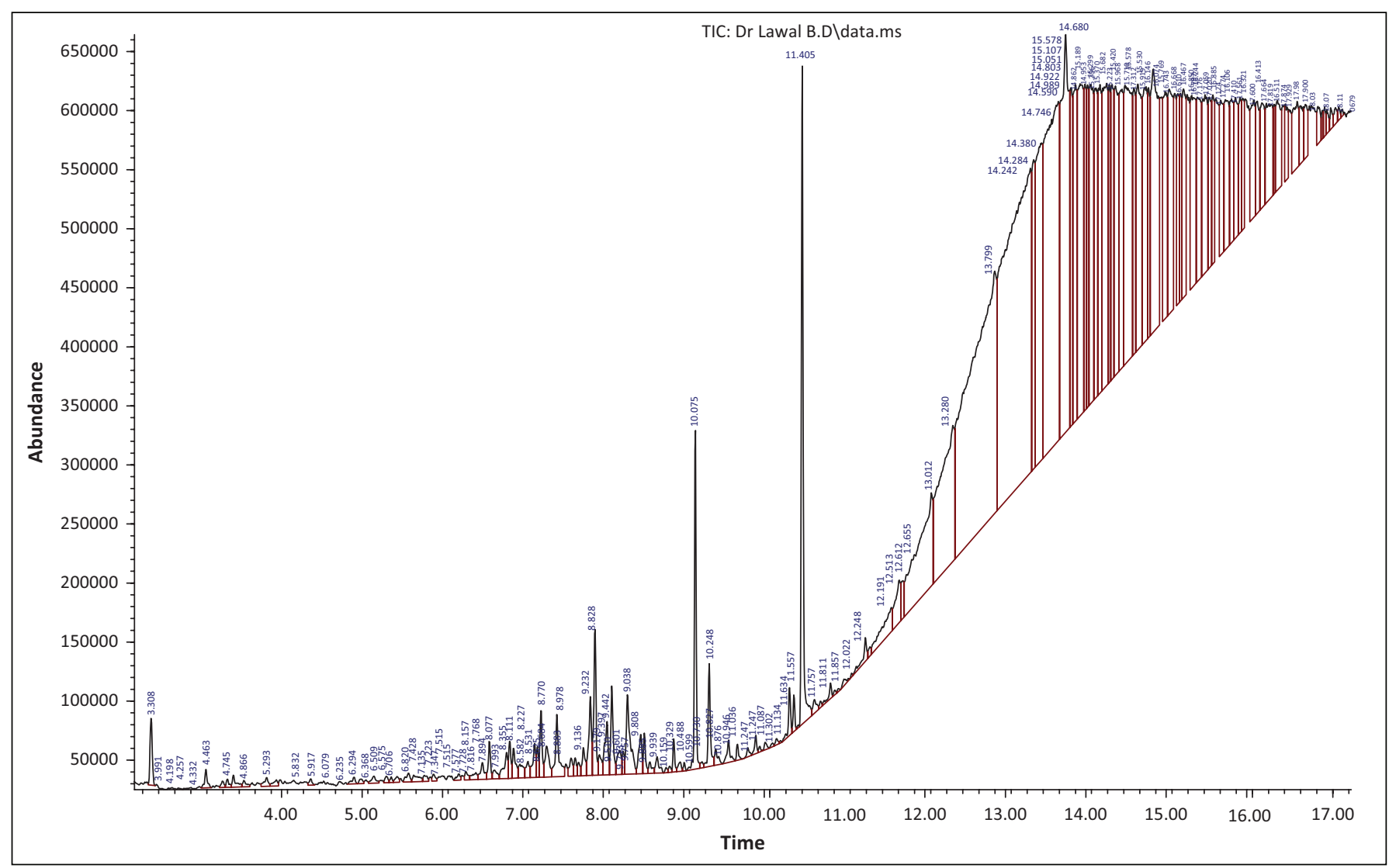

FIGURE 2: Gas chromatography-mass spectroscopy spectral data of Clausena anisata essential oil using the solvent-free microwave extraction.

of sesquiterpenes. The two oils were characterised by monoterpenes and sesquiterpenes with phenolics and oxygenated sesquiterpenes in traces. However, the essential oil obtained from SFME method was characterised mainly by sesquiterpenes.

\section{Discussion}

The essential oils of $C$. anisata contain numerous monoterpenes and sesquiterpenes, with $\alpha$-Pinene, $\alpha$.Cubebene, $\alpha$-Copaene and $\beta$.-Ocimene being the most 
TABLE 1: Kovat's index and structural formula of chemical compounds hydrodistilled from Clausena anisata.

\begin{tabular}{|c|c|c|c|}
\hline Compound name & $\begin{array}{l}\text { Chemical } \\
\text { component }\end{array}$ & Structure & $\begin{array}{c}\text { Kovat's } \\
\text { index }\end{array}$ \\
\hline $\begin{array}{l}\text { (1R)-2,6,6- } \\
\text { Trimethylbicyclo } \\
\text { [3.1.1] hept-2-ene, } \\
\mathrm{C}_{10} \mathrm{H}_{16}\end{array}$ & Monoterpenes & $\mathrm{H}$ & 758.28 \\
\hline $\begin{array}{l}\text { (1S)-2,6,6- } \\
\text { Trimethylbicyclo } \\
\text { [3.1.1] hept-2-ene, } \\
\mathrm{C}_{10} \mathrm{H}_{16}\end{array}$ & Monoterpenes & $\mathrm{H}$ & 758.28 \\
\hline $\begin{array}{l}\text { alpha.-Pinene, } \\
\mathrm{C}_{10} \mathrm{H}_{16}\end{array}$ & Monoterpenes & & 758.28 \\
\hline $\begin{array}{l}\text { (1S)-2,6,6- } \\
\text { Trimethylbicyclo } \\
{[3.1 .1] \text { hept-2-ene, }} \\
\mathrm{C}_{10} \mathrm{H}_{16}\end{array}$ & Monoterpenes & $\mathrm{H}$ & 979.35 \\
\hline $\begin{array}{l}\text { alpha.-Pinene, } \\
\mathrm{C}_{10} \mathrm{H}_{16}\end{array}$ & Monoterpenes & & 979.35 \\
\hline $\begin{array}{l}\text { 1,3,6-Octatriene, } \\
\text { 3,7-dimethyl-, (Z), } \\
\mathrm{C}_{10} \mathrm{H}_{16}\end{array}$ & Monoterpenes & & 984.08 \\
\hline
\end{tabular}

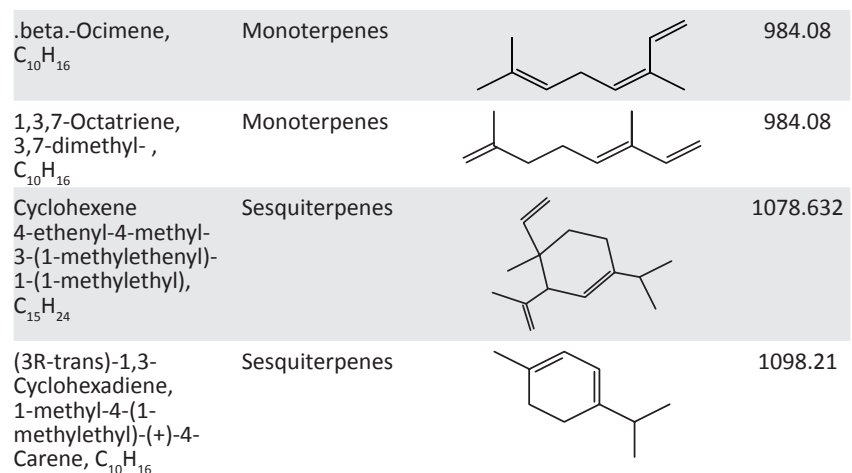

Carene, $\mathrm{C}_{10} \mathrm{H}_{16}$

.alpha.-Copaene, Sesquiterpenes

$\mathrm{C}_{15} \mathrm{H}_{24}$<smiles>CC1=CCC2CC1C1CC2(C)CCC1C(C)C</smiles>

.alpha.-Cubebene, Sesquiterpenes

$\mathrm{C}_{15} \mathrm{H}_{24}$

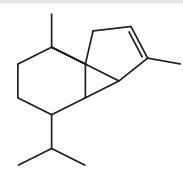

1091.64

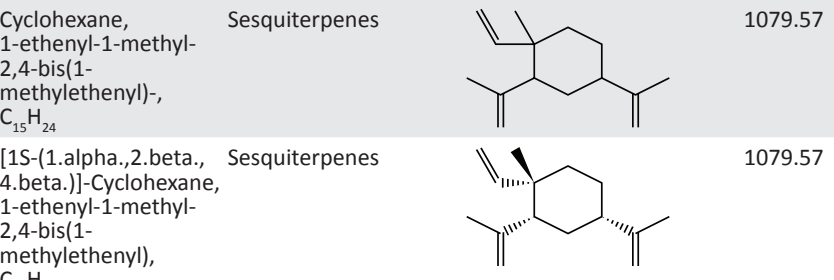

$\mathrm{C}_{15} \mathrm{H}_{24}$

Caryophyllene Sesquiterpenes

Bicyclo[7.2.0]undec-

4-ene 4,11,11-

trimethyl-8-

methylene- $\mathrm{C}_{15} \mathrm{H}_{24}$

[1R-(1R*,4Z,9S*)]- Sesquiterpene Bicyclo[7.2.0]undec-

4-ene, 4,11,11

trimethyl-8-

methylene-, $\mathrm{C}_{15} \mathrm{H}_{24}$

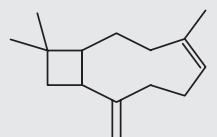

1079.57

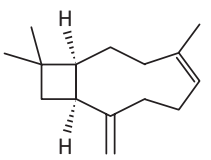

1079.57
TABLE 1 (Continues...): Kovat's index and structural formula of chemical compounds hydrodistilled from Clausena anisata.

\begin{tabular}{|c|c|c|c|}
\hline Compound name & $\begin{array}{l}\text { Chemical } \\
\text { component }\end{array}$ & Structure & $\begin{array}{l}\text { Kovat's } \\
\text { index }\end{array}$ \\
\hline $\begin{array}{l}\text { Octahydro-7-methyl- } \\
\text { 3-methylene-4-(1- } \\
\text { methylethyl)-, [3aS- } \\
\text { (3a.alpha.,3b.beta.,4. } \\
\text { beta.,7.alpha.,7aS*)]-, } \\
\mathrm{C}_{15} \mathrm{H}_{24}\end{array}$ & Sesquiterpenes & & 1122.88 \\
\hline $\begin{array}{l}\text { 1,6-Cyclodecadiene, } \\
\text { 1-methyl-5- } \\
\text { methylene-8- } \\
\text { (1-methylethyl)-, } \\
\mathrm{C}_{15} \mathrm{H}_{24}\end{array}$ & Sesquiterpenes & & 1122.88 \\
\hline
\end{tabular}

1H-Cyclopenta[1,3] Sesquiterpenes cyclopropa[1,2]

benzene, octahydro-

7-methyl-3-methylene

4-(1-methylethyl)-

$\mathrm{C}_{15} \mathrm{H}_{24}$

[3aS-(3a.alpha.,3b. Sesquiterpenes beta.,4.beta.,7

alpha.,7aS*)]-.beta-

copaene, $\mathrm{C}_{15} \mathrm{H}_{24}$

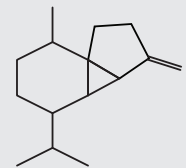

1122.88

beta.-Panasinsene Sesquiterpenes

$1 \mathrm{H}-$ Cyclopropa[a]

naphthalene, $\mathrm{C}_{15} \mathrm{H}_{24}$<smiles>C=C1CCC2CC1C1CCC2(C)CC1C(C)C</smiles>

1122.88

Naphthalene, Sesquiterpenes

decahydro-1,1,3a-

trimethyl-7

methylene-, $\mathrm{C}_{15} \mathrm{H}_{24}$

$1,2,3,5,6,8 \mathrm{a}-$

hexahydro-4, 7 -

dimethyl-1-(1-

methylethyl)

(1S-cis)-cubed

Naphthalene, $\mathrm{C}_{15} \mathrm{H}_{24}$<smiles>CC1=C2C3C(CCC2(C)CCC1)C3(C)C</smiles>

1126.81

Naphthalene Sesquiterpenes

$1,2,4 a, 5,8,8 a-$

dimethyl-1-(1-

methylethyl)-[1S-(1.

alpha.,4a.beta.,8a.

alpha.)]-, $\mathrm{C}_{15} \mathrm{H}_{24}$

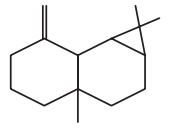

1,6,10-Dodecatrien-3- Oxygenated

ol, 3,7,11-trimethyl- sesquiterpenes

Bicyclo 7 . 2.0]

4-ene, $\mathrm{C}_{15} \mathrm{H}_{26} \mathrm{O}$



4,11,11-trimethyl-8- Sesquiterpenes

methylene-.alpha -

Farnesene, $\mathrm{C}_{15} \mathrm{H}_{24}$

Isoaromadendrene

epoxide

Cycloheptane,

$\mathrm{C}_{15} \mathrm{H}_{24} \mathrm{O}$
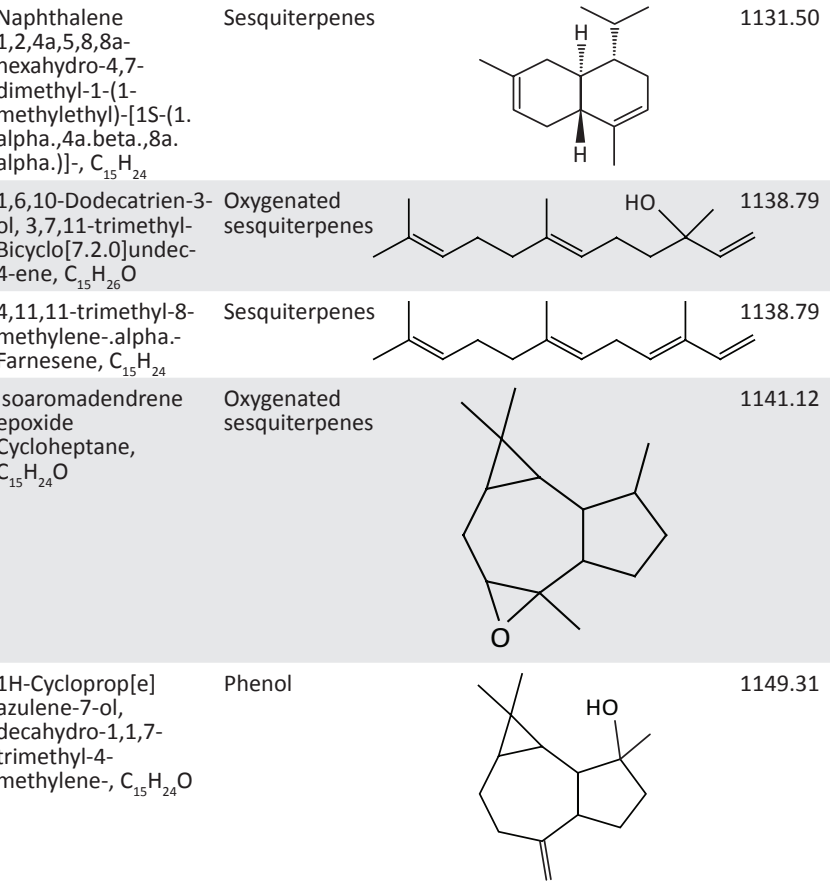

12-Oxabicyclo[9.1.0] Oxygenated

dodeca-3,7-diene, sesquiterpenes

1,5,5,8-tetramethyl-

$\mathrm{C}_{15} \mathrm{H}_{24} \mathrm{O}$

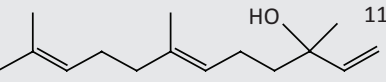

138.79

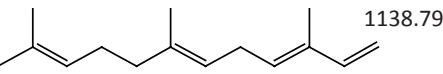

Oxygenated

1141.12
1158.28

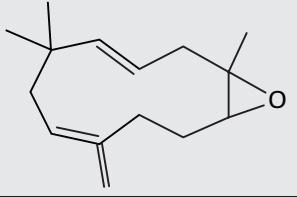

Table 1 continues on the next page $\rightarrow$ 
TABLE 1 (Continues...): Kovat's index and structural formula of chemical compounds hydrodistilled from Clausena anisata.

\begin{tabular}{llll}
\hline Compound name & $\begin{array}{l}\text { Chemical } \\
\text { component }\end{array}$ & Structure & $\begin{array}{c}\text { Kovat's } \\
\text { index }\end{array}$ \\
\hline $\begin{array}{l}\text { Alloaromadendrene } \\
\text { oxide-(1) }\end{array}$ & Sesquiterpenes \\
Alloaromadendrene & & 1164.66 \\
Naphthalene, $\mathrm{C}_{15} \mathrm{H}_{24}$ &
\end{tabular}

1,2,3,5,6,7,8,8a-octa Sesquiterpenes
hydro-1,8a-dimethyl-
7-(1-methylethenyl)-,
[1S-(1.alpha.,7.
alpha.,8a.alpha.)]-
Cyclohexene, $\mathrm{C}_{15} \mathrm{H}_{24}$
2,4a,5,6,7,8-
hexahydro-3,5,5,9-
tetramethyl-, (R),
$\mathrm{C}_{15} \mathrm{H}_{24}$

TABLE 2: Kovat's index of chemical compounds and structural formula for the solvent-free microwave extraction.

\begin{tabular}{|c|c|c|c|}
\hline Chemical compound & $\begin{array}{l}\text { Chemical } \\
\text { component }\end{array}$ & Structure & $\begin{array}{c}\text { Kovat's } \\
\text { index }\end{array}$ \\
\hline $\begin{array}{l}\text { Cyclohexene, } \\
\text { 4-ethenyl-4-methyl- } \\
\text { 3-(1-methylethenyl)- } \\
\text { 1-(1-methylethyl)-, } \\
\mathrm{C}_{15} \mathrm{H}_{24}\end{array}$ & Sesquiterpenes & & 1078.62 \\
\hline $\begin{array}{l}\text { (3R-trans)-1,3- } \\
\text { Cyclohexadiene, } \\
\text { 1-methyl-4-(1- } \\
\text { methylethyl)- } \\
\text { Bicyclo[2.2.1]hept-2- } \\
\text { ene, 1,7,7-trimethyl-, } \\
\mathrm{C}_{15} \mathrm{H}_{24}\end{array}$ & Sesquiterpenes & & 1078.62 \\
\hline
\end{tabular}

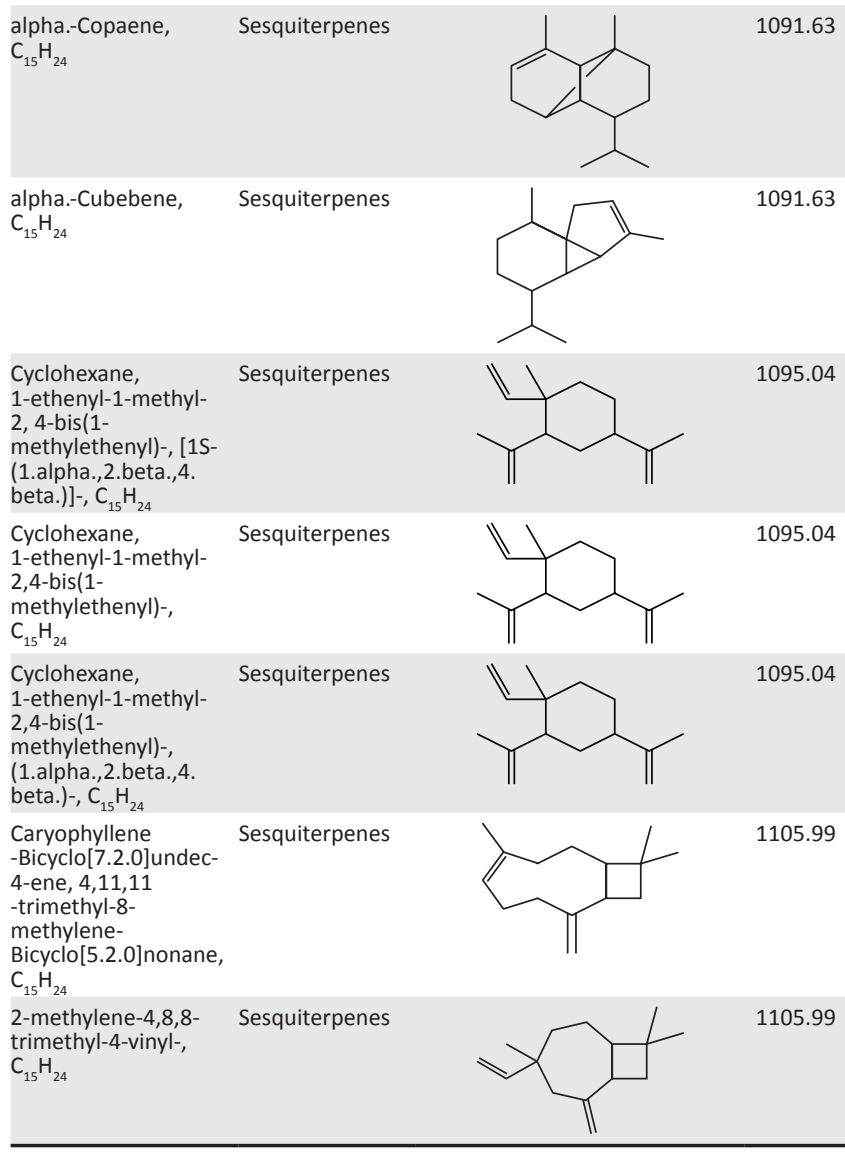

Table 2 continues $\rightarrow$
TABLE 2 (Continues): Kovat's index of chemical compounds and structural formula for the solvent-free extraction method.

\begin{tabular}{llll}
\hline Chemical compound & $\begin{array}{l}\text { Chemical } \\
\text { component }\end{array}$ & Structure & $\begin{array}{c}\text { Kovat's } \\
\text { index }\end{array}$ \\
\hline Naphthalene, & Sesquiterpenes \\
$1,2,3,5,6,8 \mathrm{a}-$ & \\
hexahydro-4,7- & \\
dimethyl-1-(1- \\
methylethyl)-, \\
$\begin{array}{l}\text { (1S-cis)-cubedol } \\
\text { cis-muurola-3,5- }\end{array}$ \\
diene, $\mathrm{C}_{15} \mathrm{H}_{24}$
\end{tabular}

predominant compounds. Monoterpenes are used for an array of therapeutic purposes such as anti-bacterial and anti-fungal treatment (Marchese et al. 2017). Sesquiterpenes are thought to be very effective in fighting cancer. The findings of this study showed that the amount of essential oils obtained through the SFME was more than that extracted through the HD extraction method from a qualitative point of view, which was still in accordance with Lucchesi, Chemat and Smadja (2004), who reported that extraction of essential oil from three aromatic herbs (basil, garden mint and thyme) using SFME method resulted in higher amounts of essential oils from both qualitative and quantitative points of view; thus, the method used for essential oil extraction will determine the type of chemical compounds found.

\section{Conclusion}

Essential oils are very important as a good source of healing to mankind. The results obtained from this study probably justify their usage in local communities for healing purposes. The SFME and HD methods of extraction gave distinctive compounds that are imperative in pharmaceuticals and cosmeceuticals. SFME yielded more essential oils than the HD method.

\section{Acknowledgements}

The authors thank the Department of Plants and Environmental Biology, KWASU for supporting the research.

\section{Competing interests}

The authors declare that they have no financial or personal relationship(s) that may have inappropriately influenced them in writing this article.

\section{Author(s) contributions}

I.O.L. designed and supervised the study; H.A. performed all the laboratory experiments; and P.O.O. generated the structures and edited the manuscript. P.D. cosupervised the study.

\section{Funding}

This research received no specific grant from any funding agency in the public, commercial, or not-for-profit sectors. 


\section{Data availability statement}

Data sharing is not applicable to this article as no new data were created or analysed in this study.

\section{Disclaimer}

The views and opinions expressed in this article are those of the authors and do not necessarily reflect the official policy or position of any affiliated agency of the authors.

\section{References}

Agbor, A.G. \& Ngogang, Y.J., 2005, 'Toxicity of herbal preparations', Camodia Journal of Ethnobotany 1(1), 23-28.

Bowles, E.J., 2003, The chemistry of aromatherapeutic oils, 3rd edn., Allen \& Unwin, Sydney.

Burkill, H.M., 1997, The useful plants of West Tropical Africa, 2nd edn., vol. 4, p. 969 , Families M-R, Royal Botanic Gardens, Richmond.

Da Porto, C., Decorti, D. \& Kikic, I., 2009, 'Flavour compounds of Lavandula angustifolia L. To use in food manufacturing: Comparison of three different extraction methods', Food Chemistry 112(4), 1072-1078. https://doi.org/10.1016/ j.foodchem.2008.07.015

Hunter, M., 2009, Essential oils: Art, agriculture, science, industry and entrepreneurship, Nova Science Publishers, Inc., New York.

Kala, C.P., 2005, 'Current status of medicinal plants used by traditional Vaidyas in Uttaranchal state of India', Ethnobotany Research and Applications 3(1), 267-278.
Lucchesi, M.E., Chemat, F. \& Smadja, J., 2004, 'Solvent-free microwave extraction of essential oil from aromatic herbs: Comparison with conventional hydrodistillation', Journal of Chromatography 1043(2), 323-327. https://doi.org/ 10.1016/j.chroma.2004.05.083

Marchese, A., Arciola, C.R., Barbieri, R., Silva, A.S., Nabavi, S.F., Tsetegho Sokeng, A.J. et al., 2017, 'Update on monoterpenes as antimicrobial agents: A particular focus on p-Cymene', Materials 10(8), 947. https://doi.org/10.3390/ma10080947

Martínez, J.L., 2008, Supercritical fluid extraction of nutraceuticals and bioactive compounds, CRC Press, Boca Raton, FL.

Nostro, A., Germano, M.P., D’angelo, V. \& Cannatelli, M.A., 2000, 'Extraction methods and bioautography for evaluation of medicinal plant antimicrobial activity', Letters in Applied Microbiology 30(5), 379-384. https://doi.org/10.1046/j.1472-765x. 2000.00731.x

Okoh, O.O., Sadimenko, A.P. \& Afolayan, A.J., 2011, 'Antioxidant activities of Rosmarinus officinalis L. essential oil obtained by hydro-distillation and solvent free microwave extraction', African Journal of Biotechnology 10(20), 4207-4211.

Omoruyi, B.E., Afolayan, A.J. \& Bradley, G., 2014, 'Chemical composition profiling and antifungal activity of the essential oil and plant extracts of Mesembryanthemum edule (L.) Bolus leaves', African Journal of Traditional Complementary Alternative Medicine 11(4), 19-30. https://doi.org/10.4314/ajtcam.v11i4.4

Pourmortazavi, S.M. \& Hajimirsadeghi, S.S., 2007, 'Supercritical fluid extraction in plant essential and volatile oil analysis', Journal of Chromatography A 1163(1-2), 2-24. https://doi.org/10.1016/j.chroma.2007.06.021

Rohloff, J., 2003, 'Cultivation of herbs and medicinal plants in Norway-essential oil production and quality control', Ph.D. thesis, faculty of The Plant Biocentre, Department of Biology, Faculty of Natural Sciences and Technology, Norwegian University of Science and Technology.

Surburg, H. \& Panten, J., 2006, Common fragrance and flavour materials. Preparation, properties and uses, 5 th edn., WILEY-VCH, Weinheim.

Swarbrick, J.T., 1997, Environmental weeds and exotic plants on Christmas Island. Indian Ocean: A report to Parks Australia, Weed Science Consultancy, Toowoomba, Queensland. 